\title{
The status of knowledge, attitude, and behaviour of postgraduate students towards Education for Sustainable Development (ESD)
}

\author{
Natasya Mohd Nizar ${ }^{*}$, Nurul Huda Ab Mutalib ${ }^{2}$, Hafsah Taha ${ }^{3}$ \\ ${ }^{1}$ Universiti Malaysia Terengganu, Kuala Terengganu, Terengganu, Malaysia \\ ${ }^{2}$ Universiti Teknologi MARA, Kuala Pilah, Negeri Sembilan, Malaysia \\ ${ }^{3}$ Universiti Pendidikan Sultan Idris, Tanjung Malim, Perak, Malaysia \\ *Email: natasyamn@yahoo.com
}

DOI: https://doi.org/10.37134/jpsmm.vol9.2.5.2019

Published: 24 December 2019

\begin{abstract}
As we race against time to save our dying home, it is more important than ever to start doing something that will help us prolong our stay on this planet. One of the efforts is by having a sustainable development (SD). United Nations Educational, Scientific and Cultural Organization (UNESCO) in 2005 have developed ESD programme to reach this goal as part of the Sustainable Development Goals (SDGs) by year 2030. This study aims to identify the level of knowledge, attitude, and behaviour of postgraduate students towards ESD as they are the changing agents and are directly inflicted by the human activities in the present. This quantitative study use questionnaire form that were responded by postgraduate students to tally the responses frequencies by using IBM SPSS Statistics 23. The findings show that there is satisfactory level of understanding towards ESD, positive attitudes towards ESD and moderate positive behaviour toward ESD.
\end{abstract}

Keywords: education for sustainable development, knowledge, attitude, behaviour, postgraduate students

\section{INTRODUCTION}

The clock is ticking, as the world's population keeps growing, the natural resources are rapidly depleting. Right now, is the best time for us to learn how to live together sustainably, if we want to save the future for the next generation. Citizens of the world, regardless of their background, age, and social status must play their part to save our dying planet. One step towards gearing to preparing environmental-literate person, is by educating with the right information and attitude. A study by Melles (2019) shows that while postgraduate students have favourable awareness in SD, they were lacking in knowledge and engagement levels. These students were enrolled in a formal sustainability degree. This shows that even with formal education, their level of embracing ESD were worrying.

Unfortunately, Malaysia does not have a formal environmental education (EE) subject or course in any educational level that can deliver the ESD topic, specifically. EE was implemented rather than embedded in university courses (Norizan, 2010). The problem arises when a teacher must implement ESD in their classes but then he does not have a full understanding of ESD nor EE. This will affect the process of integrating environmental knowledge, attitude, and behaviour in the younger generation. This is especially since there was a significant relationship between the knowledge, practice, and behaviour of the students and that of the teachers' in ESD (Hanifah \& Shaharudin, 2016). Adding in a study by Michalos, Creech, McDonald, and Kahlke (2009), it showed that attitudes was vastly more influential than education in adult respondents, thus regardless of the education, adults' attitude influences the youngsters. Since postgraduate students have higher probability to be an educator, especially in higher educational level, this study helps to identify their level of knowledge, attitude, and behaviour in ESD. 

(ESD)

ESD is an education that warrant learners to make judgements and take actions accountable to the integrity of the environment, viability of the economy and a just society for present and future generations, while respecting cultural diversity (Zakri, 2019). ESD programme was first developed by UNESCO to change the way students, youth, and educators' think and work towards a sustainable future. It is comprised of four strategies that promotes behavioural change; using economic, social, environmental, and cultural dimensions (WWF-Malaysia, n.d.). According to Al-Naqbi and Alshannag (2018), natural and social sciences and humanities provided the knowledge needed to perceive the concepts of SD, the execution process, the values and attitudes that are involved and the consequences of the applications. Attitude in this study refers to a person's views, values, feels, moral, etc. It is a cognitive and affective aspects. While behaviour implies the actions and conducts that based on the situation (Surbhi, 2017).

Identification of the current status of postgraduate students' knowledge, attitude and behaviour towards the environment is necessary to assess their level of readiness to integrate ESD in their life. The research objectives and research questions for the study are as follows.

Research objectives:

1. To identify the awareness of postgraduate students towards ESD.

2. To learn the postgraduate students' attitude towards ESD.

3. To identify ESD practice/behaviour of postgraduate students.

Research questions:

1. What is the level of awareness of postgraduate students towards ESD?

2. What is the postgraduate students' attitude level towards ESD?

3. What is the level of ESD practice/behaviour of postgraduate students?

\section{METHODOLOGY}

\section{Research design}

In order to construct a questionnaire in qualitative research, we had studied the key points in qualitative research. Artino, La Rochelle, Dezee, and Gehlbach (2014) have suggested that adapting an existing questionnaire is more efficient than building it from scratch. Therefore, for this study, the items were adopted from a study by Michalos et al. (2009) and were amended accordingly to follow Collomb's (2018) and Mora's (2016) key points for developing questionnaire; accurate, clear, singular, complete, optional, neutral, balance, order, and lastly, mode of data collection. The first version of the instrument was then validated by two experts in education field, with Cohen's $\kappa$ value at 0.91. After amendation, the finalized version of the instrument consists of a total of 44 items with knowledge, attitude and behavior sections have 15,14 , and 15 items, respectively.

Pilot study was conducted with a total number of respondent $\mathrm{N}=31$ and an excellent instrument reliability was attained $(\alpha=0.918)$.

\section{Instrument}

The instrument consists of two sections; demographic information and item constructs. For the univariate section, respondents were asked to fill-in their gender, study programme, and profession. The constructs for the second sections were knowledge, attitude, and behavior. All items have fivepoint Likert scale to express their degree of opinion with a neutral midpoint (McLeod, 2019). The questionnaire was conducted via online form due to convenience, efficiency, and environmentally friendly. 


\section{Sampling}

The respondents for this study were postgraduate students from Faculty of Science and Mathematics, Faculty of Human Development, Faculty of Human Science and the Faculty of Creative Art, Industry and Computer in one of the local universities. There was a total of 38 students in the actual study. Table 1 shows the demographics of the respondents.

Table 1 Demographics of the respondents

\begin{tabular}{|c|c|}
\hline Gender & Frequency \\
\hline Female & 29 \\
\hline Male & 9 \\
\hline Total & 38 \\
\hline Program of Study & Frequency \\
\hline $\begin{array}{l}\text { Master's in Education } \\
\text { (Biology) }\end{array}$ & 6 \\
\hline $\begin{array}{l}\text { Master's in Education } \\
\text { (Chemistry) }\end{array}$ & 1 \\
\hline Master's in Education (IT) & 5 \\
\hline $\begin{array}{l}\text { Master's in Education } \\
\text { (Mathematics) }\end{array}$ & 7 \\
\hline $\begin{array}{l}\text { Master's in Education } \\
\text { (Multimedia) }\end{array}$ & 6 \\
\hline $\begin{array}{l}\text { Master's in Education } \\
\text { (Physics) }\end{array}$ & 6 \\
\hline Master's in Geography & 4 \\
\hline $\begin{array}{l}\text { Master's in early childhood } \\
\text { education }\end{array}$ & 3 \\
\hline Total & 38 \\
\hline Profession & Frequency \\
\hline $\begin{array}{l}\text { Educator (Teachers, } \\
\text { Lecturers, etc.) }\end{array}$ & 8 \\
\hline Full time student & 30 \\
\hline Total & 38 \\
\hline
\end{tabular}

\section{RESULTS AND DISCUSSION}

Using IBM SPSS Statistics 23, the frequencies of the responses were tallied. The responses correspondent to a low level of agreements were grouped as "sd + d" and the responses correspondent to a high level of agreements were grouped as "sa $+\mathrm{s}$ ", while the indecisive responses were labeled as "nand". The number of responses for each item also included in the table labeled as "N". 
The status of knowledge, attitude, and behaviour of postgraduate students towards Education for Sustainable Development (ESD)

\section{Knowledge}

Table 2 shows the distribution of the responses towards 15 items for knowledge dimension presented in percentage. No missing value was reported.

Table 2 Responses frequency for knowledge section

\begin{tabular}{|c|c|c|c|c|}
\hline Items & sd + d & nand & $\mathbf{s a}+\mathbf{a}$ & $\mathbf{N}$ \\
\hline $\begin{array}{l}\text { K1 Sustainable development is as much about the } \\
\text { children in the future as it is about what we do and } \\
\text { need today. }\end{array}$ & 5.3 & 5.3 & 89.5 & 38 \\
\hline $\begin{array}{l}\text { K2 Corporate social responsibility is irrelevant to } \\
\text { sustainable development. }\end{array}$ & 29 & 26.3 & 44.8 & 38 \\
\hline $\begin{array}{l}\text { K3 Helping people out of poverty in Malaysia are } \\
\text { an essential condition for Malaysia to become more } \\
\text { sustainable. }\end{array}$ & 10.6 & 18.4 & 71 & 38 \\
\hline $\begin{array}{l}\text { K4 Sustainable development has nothing to do with } \\
\text { social justice. }\end{array}$ & 58 & 21.1 & 21 & 38 \\
\hline $\begin{array}{l}\text { K5 Education for sustainable development supports } \\
\text { cultural diversity. }\end{array}$ & 7.9 & 7.9 & 84.2 & 38 \\
\hline $\begin{array}{l}\text { K6 Sustainable consumption includes using goods } \\
\text { and services in ways that minimize the use of } \\
\text { natural resources and toxic chemicals and reduces } \\
\text { waste. }\end{array}$ & 5.3 & 13.2 & 81.6 & 38 \\
\hline $\begin{array}{l}\text { K7 Maintaining biodiversity (the number and } \\
\text { variety of living organisms) is essential to the } \\
\text { effective functioning of ecosystems. }\end{array}$ & 10.6 & 13.2 & 76.3 & 38 \\
\hline $\begin{array}{l}\text { K8 Economic development, social development and } \\
\text { environmental protection are all necessary for } \\
\text { sustainable development. }\end{array}$ & 7.9 & 5.3 & 86.9 & 38 \\
\hline K9 We cannot slow the rate of climate change. & 44.7 & 23.7 & 31.6 & 38 \\
\hline $\begin{array}{l}\text { K10 Use of nonrenewable resources like petroleum } \\
\text { should not exceed the rate at which sustainable } \\
\text { renewable substitutes are used. }\end{array}$ & 5.2 & 28.9 & 65.7 & 38 \\
\hline $\begin{array}{l}\text { K11 Education for sustainable development seeks } \\
\text { to balance human and economic wellbeing with } \\
\text { cultural traditions and respect for the earth's natural } \\
\text { resources. }\end{array}$ & 7.9 & 5.3 & 86.8 & 38 \\
\hline $\begin{array}{l}\text { K12 Education for sustainable development } \\
\text { emphasizes gender equality. }\end{array}$ & 18.4 & 31.6 & 50.1 & 38 \\
\hline $\begin{array}{l}\text { K13 Education for sustainable development } \\
\text { emphasizes education for a culture of peace. }\end{array}$ & 10.6 & 15.8 & 73.6 & 38 \\
\hline $\begin{array}{l}\text { K14 Conservation of fresh water is not a priority in } \\
\text { Malaysia because we have plenty. }\end{array}$ & 57.9 & 26.3 & 15.8 & 38 \\
\hline $\begin{array}{l}\text { K15 It is useful to estimate the monetary value of } \\
\text { the services that the ecosystem provides to us, such } \\
\text { as neutralizing air pollutants or purifying water. }\end{array}$ & 5.2 & 23.7 & 71 & 38 \\
\hline
\end{tabular}

Item $\mathrm{K} 1$ received the highest level of agreement with a value of $89.5 \%$ while the item with the lowest level of agreement is item K14 with a value of $57.9 \%$. Item $\mathrm{K} 12$ has the highest percentage of indecisive respond of value $31.6 \%$.

The item K1 of the section knowledge towards (ESD) showed the highest percentage for higher level of agreement. This means most of the respondents have good understanding of the concept ESD in various dimension such as environmental, social, economic and cultural. As for the lower level of agreement, the item that has the highest percentage is the item K14 that belongs to the environment dimension of ESD. The high percentage for the lower level of agreement for this item proved that the knowledge on ESD towards environment among the postgraduates are above average. 
The indecisive response with highest percentage value fell on the item K12 and it was between the value of lower and higher levels of agreement. Although this is not congruent with Michalos (2009), it is a good improvement as the percentage dropped by approximately $20 \%$ from previous findings. This shows that more people are aware the importance on gender equality in education.

\section{Attitude}

Table 3 below presented the frequency of responses from the respondents towards 14 items for attitude dimension. No missing value was reported for this data analysis.

Table 3 Responses frequency for attitude section

\begin{tabular}{|c|c|c|c|c|}
\hline Items & $\mathrm{sd}+\mathrm{d}$ & nand & $\mathbf{s a}+\mathbf{a}$ & $\mathbf{N}$ \\
\hline $\begin{array}{l}\text { A1 Poverty alleviation is an important topic in } \\
\text { education for sustainable development. }\end{array}$ & 0 & 28.9 & 71.1 & 38 \\
\hline $\begin{array}{l}\text { A2 The present generation should ensure that the } \\
\text { next generation inherits a community at least as } \\
\text { healthy, diverse and productive as it is today. }\end{array}$ & 2.6 & - & 97.4 & 38 \\
\hline $\begin{array}{l}\text { A3 Manufacturers should discourage the use of } \\
\text { disposables. }\end{array}$ & 23.7 & 10.5 & 65.7 & 38 \\
\hline $\begin{array}{l}\text { A } 4 \text { Governments should encourage greater use of } \\
\text { fuel-efficient vehicles. }\end{array}$ & 5.3 & 2.6 & 92.1 & 38 \\
\hline $\begin{array}{l}\text { A5 Every girl or boy should receive education that } \\
\text { teaches the knowledge, perspectives, values, issues } \\
\text { and skills for sustainable living in a community. }\end{array}$ & 2.6 & 5.3 & 92.1 & 38 \\
\hline $\begin{array}{l}\text { A6 Gender equality has nothing to do with } \\
\text { sustainable development. }\end{array}$ & 28.9 & 34.2 & 36.9 & 38 \\
\hline $\begin{array}{l}\text { A7 Overuse of our natural resources is a serious } \\
\text { threat to the health and welfare of future } \\
\text { generations. }\end{array}$ & 2.6 & 13.2 & 84.2 & 38 \\
\hline $\begin{array}{l}\text { A8 The teaching of sustainability principles should } \\
\text { be integrated into the curriculum in all disciplines } \\
\text { and at all levels of schooling. }\end{array}$ & 5.2 & 10.5 & 84.2 & 38 \\
\hline $\begin{array}{l}\text { A9 Sustainable development will not be possible } \\
\text { until wealthier nations stop exploiting the labour } \\
\text { and natural resources of poorer countries. }\end{array}$ & 18.5 & 18.4 & 63.1 & 38 \\
\hline $\begin{array}{l}\text { A10 We need stricter laws and regulations to } \\
\text { protect the environment. }\end{array}$ & 2.6 & 2.6 & 94.8 & 38 \\
\hline $\begin{array}{l}\text { A11 Adopting sustainable development as a } \\
\text { national priority is key to maintaining Malaysia's } \\
\text { status as one of the most livable countries in the } \\
\text { world. }\end{array}$ & 2.6 & 7.9 & 89.4 & 38 \\
\hline $\begin{array}{l}\text { A12 Companies that are environmentally } \\
\text { sustainable are more likely to be profitable over the } \\
\text { long run. }\end{array}$ & 5.2 & 26.3 & 68.4 & 38 \\
\hline $\begin{array}{l}\text { A13 There is no point in getting involved in } \\
\text { environmental issues, since governments and } \\
\text { industries have all the power and can do what they } \\
\text { like. }\end{array}$ & 52.6 & 5.3 & 42.1 & 38 \\
\hline $\begin{array}{l}\text { A14 Citizenship education is an important } \\
\text { component of education for sustainable } \\
\text { development. }\end{array}$ & 5.3 & 23.7 & 71.1 & 38 \\
\hline
\end{tabular}

The item with highest percentage for higher level of agreement was A2 with a value of $97.4 \%$. As for the highest percentage for the lower level of agreement, item A13 has the highest value of $52.6 \%$. item with the highest percentage of indecisive responses was A6 with the value of 34.2\%. 
The status of knowledge, attitude, and behaviour of postgraduate students towards Education for Sustainable Development (ESD)

In the attitude section, item A2 is in line with the highest percentage of higher level of agreement in the knowledge section that also belongs to the environment dimension. Item A13 has the highest value which also belongs to the environment dimension of ESD. Item with the highest percentage of indecisive responses was A6 of the social dimension of ESD. The value was around $30 \%$ and is as high as the percentage of higher level of agreement for this item. This shows that despite the increase of awareness in knowledge about gender equality, the attitude towards gender issue in sustainable development is still below expectation.

\section{Behavior}

The frequency for the responses of behavior dimension was presented in the Table 4 below with a total of 15 items.

Table 4 Responses frequency for behavior section

\begin{tabular}{|c|c|c|c|c|}
\hline Items & $\mathbf{s d}+\mathbf{d}$ & nand & $\mathbf{s a}+\mathbf{a}$ & $\mathbf{N}$ \\
\hline B1 I volunteer to work with local charities. & 5.2 & 31.6 & 63.1 & 38 \\
\hline $\begin{array}{l}\text { B2 I invest my savings in funds that are ethically } \\
\text { responsible. }\end{array}$ & 13.1 & 44.7 & 42.1 & 38 \\
\hline B3 I often look for signs of ecosystem deterioration. & 5.2 & 31.6 & 63.2 & 38 \\
\hline $\begin{array}{l}\text { B4 I talk to others about how to help people living in } \\
\text { poverty. }\end{array}$ & 7.9 & 39.5 & 52.6 & 38 \\
\hline $\begin{array}{l}\text { B5 I have changed to environmentally friendly light } \\
\text { bulbs. }\end{array}$ & 10.5 & 26.3 & 63.2 & 38 \\
\hline $\begin{array}{l}\text { B6 I try to ensure that there is gender equity in my } \\
\text { home, my work and my volunteer environments. }\end{array}$ & 18.4 & 39.5 & 42.1 & 38 \\
\hline $\begin{array}{l}\text { B7 I try to avoid purchasing goods from companies } \\
\text { with poor track records on corporate social } \\
\text { responsibility. }\end{array}$ & 2.6 & 42.1 & 55.2 & 38 \\
\hline $\begin{array}{l}\text { B8 I have changed my personal lifestyle to reduce } \\
\text { waste. }\end{array}$ & 10.5 & 10.5 & 79 & 38 \\
\hline B9 At home I try to recycle as much as I can. & 13.2 & 10.5 & 76.3 & 38 \\
\hline $\begin{array}{l}\text { B10 The household tasks in my home are equally } \\
\text { shared among family members regardless of gender. }\end{array}$ & 21 & 26.3 & 52.6 & 38 \\
\hline $\begin{array}{l}\text { B11 I have a home composting system or use the } \\
\text { municipal green box system. }\end{array}$ & 47.3 & 31.6 & 21.1 & 38 \\
\hline B12 I walk or bike to places instead of going by car. & 39.5 & 18.4 & 42.1 & 38 \\
\hline B13 I opt for public transports whenever possible. & 15.8 & 23.7 & 60.5 & 38 \\
\hline $\begin{array}{l}\text { B14 I do not use chemical fertilizers or pesticides on } \\
\text { my plants. }\end{array}$ & 15.8 & 44.7 & 39.5 & 38 \\
\hline $\begin{array}{l}\text { B15 I have taken a course in which sustainable } \\
\text { development was discussed. }\end{array}$ & 23.7 & 13.2 & 63.1 & 38 \\
\hline
\end{tabular}

Item B8 has the highest percentage of 79\% for the higher level of agreement while item B11 has the highest percentage of lower level of agreement with a value of $47.3 \%$. There were two items with the same highest values of indecisive responses; B2 and B14 with the value $44.7 \%$ for both items.

More than half of the responses gave positive response on item B8. This means that the good habits of sustainability have taken shape among the postgraduates. As for the highest percentage of lower level of agreement, item B11 has the highest value. There are few constraints to adhere to this item such as the availability of the green box system and the residence of the respondent. Starting a home composting system requires space, preferably landed residence as the process would emit uncomfortable smell. Hence, most responses are negative responses for this item. The two items with 
the same highest values of indecisive responses are B2 and B14, nearing half of the responses. The reason for item B2 could be due to the ambiguous nature of the item itself and item B14 could have the similar reasoning as the item $\mathrm{B} 11$.

\section{CONCLUSION}

To sum up the findings for this study, the level of awareness among the postgraduates happen to be at satisfactory level, especially in the environmental dimension of ESD. There are positive attitudes toward ESD detected from the results and the behaviour of the postgraduates toward ESD are at moderate level. Other dimension of ESD also has positive responses also not as much as environmental dimension. It is important to know that sustainability does not only concern the environment, but also economy, social and culture. Future study could provide more detailed exposure about ESD with equal emphasize on all the dimensions involved.

\section{REFERENCES}

Al-Naqbi, A.K. \& Alshannag, Q. (2018). The status of education for sustainable development and sustainability knowledge, attitudes, and behaviors of UAE University students. International Journal of Sustainability in Higher Education, 19(3), 566-588. doi: 10.1108/IJSHE-06-2017-0091

Artino, A.R.J., La Rochelle, J.S., Dezee, K.J., \& Gehlbach, H. (2014). Developing questionnaires for educational research: AMEE Guide No. 87. Medical Teacher, 36(6), 463-474. doi:10.3109/0142159X.2014.889814

Collomb, J. (May 03, 2018). 7 key points for asking the right questions in your questionnaires. Retrieved from https://www.myfeelback.com/en/blog/7-key-points-for-asking-the-right-questions-in-yourquestionnaires

Hanifah Mahat \& Shaharudin Idrus. (2016). Education for sustainable development in Malaysia: A study of teacher and student awareness. Malaysian Journal of Society and Space, 12(6), 77 - 88.

McLeod, S. (2019). Likert scale definition, examples and analysis. Retrieved from https://www.simplypsychology.org/likert-scale.html

Melles, G. (2019). Survey study on attitudes to multi-dimensional sustainable development with U.K. MSc students. Social Sciences, 8(3), 7. doi:10.3390/socsci8030075

Michalos, A. C., Creech, H., McDonald, C. \& Kahlke, P. (2009). Measuring knowledge, attitudes and behaviours towards sustainable development: Two exploratory studies. Manitoba, Canada: International Institute for Sustainable Development.

Mora, M. (November 05, 2016). Survey tips: 10 key things to consider when designing surveys. Retrieved from https://www.surveygizmo.com/resources/blog/designing-surveys/

Norizan \begin{tabular}{ccc}
\multicolumn{1}{c}{ Esa. } & Environmental & knowledge,
\end{tabular} attitude and practices of student teachers. International Research in Geographical and Environmental Education, 19(1), 39-50. doi: 10.1080/10382040903545534

Surbhi, S. (October 28, 2017). Difference between attitude and behavior. Retrieved from https://keydifferences.com/difference-between-attitude-and-behavior.html

United Nations Educational, Scientific and Cultural Organization (UNESCO). (n.d.). Global Action Programme on Education for Sustainable Development (2015-2019). Retrieved from https://en.unesco.org/globalactionprogrammeoneducation

WWF-Malaysia. (n.d.). Education for Sustainable Development (ESD). Retrieved from http://www.wwf.org.my/about_wwf/what_we do/education_for_sustainable development_esd /

Zakri Abdul Hamid. (June 04, 2019). Revisiting education for sustainable development. Retrieved from https://www.nst.com.my/opinion/columnists/2019/06/493960/revisiting-education-sustainabledevelopment 